\title{
SHADES OF AFRICAN VALUES AND INTERESTS IN NIGERIA'S INTERNATIONAL RELATIONS: INVESTIGATING THE GAINS AND THE COSTS, 1960 - 2014
}

\section{Amaechi Alex Ugwuja}

http://dx.doi.org/10.4314/og.v12i s1.3

\begin{abstract}
Nigeria's emergence as a player on the international theatre heralded myriad hope for the African continent. Consequently, Nigeria's debut in the seemingly anarchical international system (I.S) was fastened to a philosophical praxis that centered unmistakably on African interests and values. However, findings in extant literature indicate that Nigeria has not gained commensurably in predisposing her international relations to be conditioned primarily by African interests and values. With the theoretical binoculars of the Constructivist Theory, and adopting the specific cases of Nigeria's bilateral relations with Angola, South Africa and Ghana, this study investigates the gains and costs of contriving Nigeria's International Relations (N.I.R) to be essentially based on African values and interests. The paper argues that 'African values and interests' as a philosophical praxis may have favoured Nigeria considerably in other domains but not in her International Relations (I.R); as indeed, "she gave and gave and in return got nothing". The study does not only recommend the pressing need of dismantling, overhauling and reinventing the philosophical foundations of Nigeria's I.R (as this has been proposed by some extant studies) but also the engagement of policies that ensure that the country recovers all she lost in her years of naivety in I.R. The study adopted the historical methodology which emphasizes critical analyses and interpretation of facts. Data for the study came largely through secondary sources and a few primary sources in the form of Government documents and confidential reports.
\end{abstract}

\section{Introduction}

The emergence of Nigeria in 1960 as a sovereign state with all the trappings of a modern state and potentials of greatness qualified her for full membership of the International System (I.S), wherein the 
seemingly squalid business of International Relations (I.R) is conducted. Nigeria consummated her sovereignty by becoming the $99^{\text {th }}$ member of the United Nations - the fulcrum of contemporary I.R, on October 7, 1960 (Gambari, 187). From the outset, Nigerian policy - makers made it clear that independence would amount to little or nothing; except it was employed to pursue the aim of further decolonization of the continent. This resolve was boldly projected in the maiden address of Nigeria at the $15^{\text {th }}$ regular session of the United Nations General Assembly where the late Prime Minister, Sir Abubakar Tafawa Balewa articulated the broad principles of Nigeria's international relations. Among other principles, the Prime Minister declared inter alia that African values and interests would serve as the anchorage of Nigeria's I.R. Consequently, and on the basis of African values and interests, Nigeria swore to assist in the eradication of Apartheid in South Africa and the promotion of responsible independence for those African countries still under colonial domination on the continent.

It must be understood that this lofty aim was conditioned partly by the wave of Pan - Africanism in the world and especially, the contribution of Nigeria's leaders to that cause, particularly, the doyens of Nigerian nationalism, Dr. Nnamdi Azikiwe and Chief Obafemi Awolowo. Presenting his inaugural address on the occasion of Nigeria's independence and his installation as the Africa's first indigenous Governor - General, Dr. Azikiwe averred:

The challenge of Nigeria as a Free State in the twentieth century Africa is the need to revive the stature of man in Africa... we cannot concede that it is in our national interest to fraternize with such nations which practise race prejudice and we must not acquiesce in such an outrageous insult on the black man. In fact, we must regard it as a mark of disrespect and an unfriendly act if any country with whom we have friendly relations indulge in race prejudice in any shape or form, no matter how it may be legally cloaked. (Azikiwe, 8)

With the above framework, subsequent Nigerian governments considered Nigeria's international relations to be founded on the 
'immoveable rock' of African values and interests and proceeded to exert enormous financial, political and ideological energies for the betterment of the African continent. Nigeria's role was so central to the struggle against Apartheid that the United Nations allowed her to serve for up to twenty years as Chairman of the United Nations Special Committee against Apartheid (Gambari, 189). South Africa was also to declare Nigeria a frontline state, in acknowledgement of Nigeria's crucial crusading struggles against Apartheid (Otubanjo, 78). Elsewhere in Angola, Nigeria doled out millions of dollars to support that country's liberation struggles. Several other instances abound to buttress the commitment of Nigeria to Africa - her values and interests.

How far this international relations trajectory has helped Nigeria in the achievement of her national interest has become a great debate in Nigeria's foreign policy and I.R discourses. Thus, the statement of this study's problem may simply read: 'African values and interests' as a philosophical praxis may have favoured Nigeria considerably in other domains but not in her International Relations (I.R). This is because in formulating foreign policy objectives, every state makes an analytic distinction between interests which are critical to its very existence and those that are not. The first group is called vital interests, while the second group is called secondary interests (Ade - Ibijola, 566). It would appear that Nigerian policy makers over the years mistook the country's secondary interests for its vital interests.

However, to provide a balanced assessment of the problem, an investigation of the gains and costs of contriving Nigeria's International Relations (N.I.R); based on African values and interests is made in the study; specific case studies of Nigeria bilateral relations with Angola, South Africa and Ghana is adopted. For ease and convenience, the study is divided into six sections. This introduction is directly followed by the conceptual and theoretical framework. The third section essays on African values and interests as philosophical foundations of Nigeria's I.R. The fourth part discusses the gains of African values and interests as enablers of N.I.R. The penultimate sections $\mathrm{x}$ - rays the costs of African values and interests on N.I.R. The study is concluded in the sixth part which also contains the recommendations. 


\section{Conceptual and Theoretical Frameworks}

Values have been seen as the ideas that propel man's daily actions; they are the standards which members of the community adhere to in their personal and communal interaction towards the achievement of the goals (Igboin, 98). In a sense, values refer to what is 'good' or 'desired'. Put differently, values refer to the usefulness or worthwhileness of anything. By extension, African values showcase the worthwhileness of Africa and Africans.

But we should not delude ourselves to believe that African values mean one and the same thing throughout Africa. At best, the term African values is a motley of issues from which the African way of life can be appreciated. These issues include: (i) Sense of the sacredness of life; (ii)Sense of hospitality and philanthropy; (iii) Sense of community life and brotherliness; (iv)Sense of good human relations; (v) Sense of the sacred and of religion; (vi) Sense of time; (vii) Sense of respect for authority and the elders; (viii) Sense of language and proverbs and the like.African values appear to have been summed in one single concept - the concept of African Personality. This is because according to Alex Quaison - Sackey the African Personality is:

In the largest sense, the cultural expression of what is common to all peoples whose home is on the continent of Africa. the fact that the great majority of these people have black skin is, to be sure, important but of greater importance is the fact that the African Personality - by attempting to transcend its specific physical and intellectual environment, yet without pulling up the roots that nourish it hopes to create as a force for world peace and unity, a dynamic political creed. Such a creed will express itself through that personality which embraces the qualities of man as a citizen of Africa and as a member of the human race (Quaison - Sackey, 35).

What can be gleaned from the above remarks is that the ultimate aim of African values is to restore the dignity of Africa and the African. Lastly, African values have been influenced by two significant external phenomena - Islam and Western cultures. Often, the 
principles animating these external influences conflict with each other and also with the traditional African values. "What is to be done", writes Nkrumah (73) "is that the two external influences must be accommodated only as experiences of the traditional African society". "If we fail to do this" Nkrumah (73) concludes, "our society will be racked by the most malignant schizophrenia".

African interests on the other hand, refer to the finding of solutions to a plethora of challenges that confront the continent. Students and scholars of International Relations would not but agree that the interests of a people are not static but dynamic. African interests have transmuted from asserting the African Personality, decolonization to security and development among others.

Lastly on conceptual framework, international relations is to be distinguished from International Relations. The former refers to the multifarious relationships between and amongst sovereign states and other actors on the international stage. The later implies a study of the former i.e. the study of the multifarious relationships between and amongst sovereign states and other actors on the international stage. Often, international relations is taken as co - terminable with such terms as foreign policy and diplomacy; although, this fusion would appear unwieldy in a meta - critical discourse. Foreign policy refers to a set of programmes pursued by a state in relations with other states. Diplomacy serves as the conduit or machinery for implementing the stated objectives of state. In this discourse, the terms international relations and foreign policy are often used co terminably.

This study requires a theoretical framework and hence, the Constructivist Theory is evaluated and used. The constructivist theory traces its root to the pioneering work of Nicholas Onuf, Richard K. Ashley and Alexander Wendt (Ugwuja, Ibekilo and Ekesiobi, 17). Constructivism primarily seeks to show how international relations (wherein foreign policy is anchored) is constructed. Constructivism holds that it is ideas and not realities that inform the decision of sovereign states. The theory attempts to explain how the historical and social formations of a country create ideas which are often interpreted as realities in international relations (Griffiths, 52). Alexander Wendt who is by far the most vocal enunciator of this theory maintains that "anarchy is what states make 
of it" (Wendt, 385).Constructivism considers international politics as a sphere of interaction which is shaped by the actor's identities and practices and also influenced by constantly changing normative institutional structures. It maintains that states' goals, either material or (objective goals) such as security and economic development or immaterial or (subjective goals) such as international recognition and prestige are generated by their social corporate identities or how they view themselves or other actors in international politics.

The basic assumption of the constructivist theory may be rendered into the following:

(1) States are the principle units of analysis for international political enquiry

(2) State identities and interest are constructed primarily based on perception rather than reality.

(3) The key structures in the state system are inter-subjective rather than material(Ugwuja, Ibekilo and Ekesiobi, 17).

Applying this theory to this present study, one can argue that the promptings for and reliance on African values as the philosophy of Nigeria's I.R has been a mere reflection of our corporate identities and self- perception rather than concrete political and economic realities, especially, the later. It cannot be argued that at independence Nigeria saw herself as a "giant" by virtue of its stupendous resources, endowments and population. Nigeria therefore constructed a foreign policy which feeds more on self- perception rather than on concrete political reality. This explains why her philanthropic gestures were made without much cost and benefit analysis.

Although, constructivism as a theory explicates Nigeria's foreign policy lacuna, it is not without inherent weaknesses. For one, we know that is a state -centric/real politik orientated theory that tends to neglect the influence/impact of other actors of international relations.

\section{Philosophical Foundations of Nigeria's International Relations: The African Values and Interests Nexus}

Until recently, very little scholarly attention was given to the philosophical foundations of Nigeria's international relations. Most scholars of International Relations assumed that philosophical enquiries in such a heady discipline as International Relations were 
extraneous. L.A Jinadu provides apt insight into this lacuna when he submits that "the neglect of the interface between philosophy and foreign policy is not peculiar to our study of Nigeria's external relations or international relations. It applies equally to our study of domestic public policy". (18)

Furthermore, Jinadu avers:

The reason for this lacuna in our intellectual works emanates from the fact that our mainstream methodological perspective confer on structure and by extension, process, since structure implies process as a reference the ecology of public policy or public administration, the critical even casual determinant of public policy. While we confer autonomy on structure in shaping policy, we tend to regard ideas, in the form of moral and political philosophy, as "epiphenomenal" (18).

Perceptions of the 'external reality' and how to respond to it - the substance of I.R - are influenced by the world views of individuals, by the purpose and ends of government and by what needs to be done to pursue collective development. "These" writes, Jinadu "are philosophical issues which invariably provide the ideational context for determining policy programmes and objectives". It is to be noted that every policy /activity starts from an idea. Thus, subjecting policies to philosophical scrutiny would certainly sieve the irrelevancies from policies and thus enhance their achievability. This cannot be claimed to have wholly been the case vis ả vis Nigeria's foreign policy and I.R.

The above viewpoints should not be misconstrued to suggest that Nigeria's foreign policy have no philosophical connotations. The point is that as a critical scrutiny of the wisdom inherent in the choice of certain international relations engagements of Nigeria, philosophy has had little consultation. The following issues have functioned as the basis of Nigeria's I.R: (i) Decolonization of the African continent; (ii) leadership of the African continent; (iii) selfdetermination and self-government; (iv) non - alignment; (v)internationalism/inter - dependence; (vi) removal of the global 
asymmetric order; (vii) economic development among others. From these, one can see the imprints of African values and interests on Nigeria's I.R.

\section{An Appraisal of the Gains of African Values and Interests as Actuators of Nigeria's I.R}

In most extant literature on Nigerian foreign policy and international relations, Nigeria's predication of her I.R on African values praxis is often criticized as having had no strategic or developmental value for the country. This is not always the case; indeed, African values and interests as basis for Nigeria's I.R served a useful purpose at a particular period in the history of the country; when she needed to assert herself on the African continent. From whatever angle we look at it, especially, in the 1970's, we can assuredly notice that it helped to boost Nigeria's image in not only her African international relations but indeed the global theatre.

Unarguably, a country's external image is an important aspect in its international relations. The United States of America and some European states that prod other states on the international stage are able to so, because of an intimidating image they have garnered over the years. In any case, Nigeria's image soared in the world consequent upon the enunciation of the principle of African values and interests as the 'center piece' of her foreign policy. As stated elsewhere in this study, Nigeria made it clear that her independence would amount to nothing if some parts of Africa were still under colonialism. Hassan Saliu writes that "massive material and human resources were placed at the disposal of liberation movements" (226). Nigeria was not intimidated by the fact that the Western world, being essentially the colonizers, would collide with her in their relentless pursuit of colonialism and neo-colonialism. Furthermore, Hassan Saliu notes that "the Murtala administration promptly recognized the MPLA and geared up material and diplomatic support for the party. The granting of a financial aid of \$20 million climaxed Nigeria's support for the party" (231)

What is more, the policy of nationalization of the assets of BP in Shell-BP taken in July 1979 by the Obasanjo regime over the issue of Rhodesian independence complimented the Angolan policy to promote a good image for Nigeria (Saliu, 236). Perhaps more than this, Nigeria's moral and anti- apartheid stance was instrumental to 
her recognition as a clear leader on the African continent in the 1970s. Nigeria's concern for the political struggle of South Africa earned her a well-deserved membership of the frontline states of Southern Africa (Garba, 111).

The sum total of all this, according to Joseph Garba revealed themselves in 1977, when Nigeria against all odds secured the African non-permanent UN-Security Council seat at the expense of Niger (77). Nigeria's African foreign policy afforded Nigeria leadership of all blacks all over the world as many of them came to identify with Nigeria. "Indeed the history of the second black Festival of Arts \& Culture (FESTAC) in 1977 in Lagos, rekindled the interest of blacks all over the world and promoted the goal of pan-Africanism" (Garba, 92). In contemplation of the foregoing vis a vis the gains of Nigeria's Africa foreign policy in the $20^{\text {th }}$ century, Hassan Saliu reports that;

Nigerians visiting other countries were proud of the respect they enjoyed. Apparently informed of the country's oil wealth and influence, many nations believed that Nigerians were going to contribute positively to their national economies. Nigeria was the target of international financial institutions which had excess money to lend to the country due to her economic viability (Saliu, 226).

Furthermore, Hassan Saliu informs us that:

The country, Nigeria's financial suitors propounded the thesis of under borrowing in their judgment, the debt overhang of Nigeria, which until 1978 was computed in millions, qualified her as an under borrowed country. Her minerals and human resources could sustain a bigger debt figure (Saliu, 226).

The usefulness of Nigeria's Africa policy derives from the saying that a good name is better than riches. Without doubt, Nigeria's 
Africa policy projected Nigeria and enhanced her image throughout the globe, especially, in the 1970s. Nonetheless, several disadvantages arise and continue to do so as result of basing Nigeria's I.R on African values and interests. This is given attention in the following section.

\section{The Costs of Basing Nigeria's International Relations on Africa Values and Interests: The Case of Angola}

Nation states all over the world fashion their foreign policy to guide external relations, as well as to protect, promote and defend their vital national interests of which promotion of economic viability is paramount. It is, therefore, naturally expected that at any point in time, Nigeria's international relations as captured in the foreign policy should be a reflection of the aspirations for the well- being of the ordinary Nigerian, because as stated earlier, a country's foreign policy is a reflection of the domestic policy. How far Nigeria's Africanist policy of the $20^{\text {th }}$ century succeeded in bettering the lives of the generality of Nigerians is not so much an academic question for even the blind could see that we gained little (compared with what was lost).

A study of the various engagements made by Nigeria within the confines of a foreign policy/ international relations powered by african values and interests such as decolonization of the continent, Peace- keeping missions, bilateral and multilateral financial aid to African states shows that Nigeria's Africa foreign policy philosophy does not appear to be well- aligned to the country's core national interests. Simply put, Nigeria Africa foreign policy has not served the national interest in a commensurate measure. Let us start with Nigeria's misdeeds in Angola.

After several centuries of colonial exploitation of Angola and a brutally disarticulated economy based on cassava, the Portuguese, owing to the wind of change and militant agitations of their colonies announced their withdrawal from Angola come November $11^{\text {th }}, 1975$. Meanwhile, three political parties - MPLA, FNLA and UNITA had become ferociously entangled in a deadly contest for the leadership of the soon - to - be - independent Angola. While other African states weighed the evolving crisis from the standpoint of their national interests, Nigeria without weighing the pros and cons of the matter and believing it reflected more 
African values to give without thinking declared support for the MPLA; majorly because the West were sponsoring the rival factions. No reciprocal agreement(s) were made with the Angolans on the assistance offered by Nigeria. Joe Garba writes that:

Once we accorded recognition, things moved with what came to be thought of as Murtala - esque speed. An outright grant of twenty million dollars was made to the MPLA Government; military hardware from rifles to MiGs, supplies from clothing to composite rations, were sent in ever increasing quantities. Nigeria's "radicals" and slumbering political correspondents had a field day, and anyone particularly in the foreign ministry whose perspective went beyond dramatic effect in the immediate days ahead, and who asked about a quid pro quo for Nigeria's lavish support was derisively overridden... now here was twenty million dollars in cash going to Angola without a discussion even what might gain, or even what uses it would be put to (Garba, $23-26$ ).

The financial aid to Angola has borne no reciprocal fruits whatsoever. Joe Garba who was Nigeria's external affair commissioner in 1975 later saw the uselessness of such a gesture. He regrets that two years later, that is by 1977 "no one could pin down a normal Angola to any form of bilateral agreement'. In the opinion of the present researcher, the Angolan government and people have only (both in the past and now) repaid the Nigeria people that bore the ransom for their nationhood with evil. The Africanist philanthropic gesture did not stop at the twenty million dollars grant, indeed, all manners of assistance were rendered including housing, releasing several Nigerian aircrafts to Angola. Indeed, when Angola was stable to run their own aviation industry, they obstinately refused to have flights from Luanda to Lagos; Nigerians who wished to travel to Angola had to fly first to Portugal before moving to Angola. 
In fact, to the Angolans, Nigeria was only a "father Christmas" with a big load of goodies. Despite all Nigeria did for Angola, Nigeria's name was conspicuously absent from the list of the countries Angola paid tribute to, for assisting them in their independence struggle at their first appearance at the O.A.U summit in Mauritius in July 1976. To cap it all, Nwanolue and Iwuoha (85) write that after Murtala's death, it took Angola three whole weeks to express their condolence over the death of their benefactor. "When eventually the message did arrive from Angola, only its first three sentences made any reference to our loss; the remainder contained another shopping list" (85).The embarrassing frustration and betrayals from the Angolans cannot be exhausted in this study. Often, Nigerians living in Angola are hunted like animals. Indeed, whatever we have done for them in the past meant little and presently means nothing to them.

Nigeria's African policy can thus be seen as a case of acting without thinking. How can a nation where half of the citizens were (are) living below the poverty line waste resources on gifts and grants to needy countries without thinking of benefits accruable to her. As students and scholars of international politics, we do know that there is no free diner, every supposedly altruistic favor has a strategic cum realist underpinning, which may be for the medium or long term. In the case of Angola discussed above, Joe Garba summarizes the point quite succinctly:

In implementing this otherwise admirable policy, we let our enthusiasm for the MPLA's success against its Western and South African backed rivals run away with us. As we have seen, the benefits to Nigeria as a result were no more than those that came to those countries who just sat back and watched. Stripped of emotional commitment, our working of the system of international relations in which the national interest is always in view and reciprocity is always a constant factor, we did not get high marks (37).

He further queries: 
What, after all did Nigeria gain? High visibility in the international community; an awakening of our government officials as to what serious lobbying involved; and rallying a large percentage of our population to an international cause. But in bilateral terms which are, after all, the corerelation between states, we gave and gave to Angola, in return got nothing (37).

It is not a fallacy for one to posit that there has been an apparent disconnect between Nigeria's national interest and Nigeria's Africa relations. For it is alarmingly glaring that Nigeria has done so much for the Africa continent without any commensurable and corresponding positive outcomes. In this regard, Inno Ukeje avers that "our false generosity abroad and penury at home are proof that we are pretending to be what we are not because in reality, we have been overstretching ourselves"(Ukeje, 25). One cannot but agree with this scholar of international relations. What is more, Nigeria's Africa policy has even backfired to haunt Nigeria and Nigerians. Most African countries are wont to believe that Nigeria wants to use her vast demographic and natural resources to intimidate them thereby establishing unrivaled hegemony. Some African countries believe that Nigeria is a spent force whose citizens have had to leave their country to despoil other countries. This in turn has led to a wave of xenophobic attacks on Nigerians all over Africa. Most of these African countries erect wicked and harsh trade policies against Nigerians in their countries. The list is endless: Ghana, Angola, South Africa and the Congo etc.

\section{The Case of South Africa}

Unarguably, Nigeria's relationship with South Africa is determined by several factors. Nonetheless, historical factors occupy the mode in the frequency of these factors. South Africa is a country, whose African people probably would still have been struggling to eke out a meager existence in the back waters of their own country, had Nigeria not emboldened herself and flexed her muscles to rescue fellow Africans, who were deluged with oppression and humiliation in the southernmost tip of the continent (Ugwunne, 34). Nigeria's 
efforts were crucial in the final triumph of South African against the obnoxious Apartheid behemoth. Joseph Garba's book, Diplomatic Soldiering and a host of other literatures have amply underscored the multidimensional assistance of Nigeria to South Africa. It may be unwieldy to go through the abundant occasions in which Nigeria exerted herself enormously to ensure that South Africa gained independence. However, a few will suffice to explain the position of this present study. It is instructive to note that Nigeria's engagements in South Africa were actuated by her Africanist values and interests.

Nigeria provided the fulcrum and a rallying point in the struggle against apartheid by mobilizing states that abhorred the evil practice to tighten international pressures against South Africa. Often, Nigeria went solo and engaged policies that could be inimical to her economic survival; she was indeed willing to endure all the negative darts thrown at her by the supporters of Apartheid. What is more, the struggle was to take a dramatic turn during the regime of Murtala/ Obasanjo, 1975- 1975; it was so momentous that domestic awareness was mounted to the extent that students of many tertiary institutions formed clubs like the Youth Solidarity on South Africa where these students contributed money from their pocket monies which they remitted to the South Africa Relief Fund (SARF) earlier created by the Ministry of Foreign Affairs. More than $\$ 30$ million was thus generated and transferred to the South African freedom fighters (Garba, 102).

Furthermore, the Murtala - Obasanjo regime, in a successful attempt to send warning signals, to the whole world, that it would not tolerate, nor flirt with any country doing business with the white minority regime in South Africa, nationalized the local operations of Barclays Bank in Nigeria, after that bank ignored the strong protests by Nigeria, advising it, not to buy the South African government bond, which would be in violation of the economic/trade embargo on the racist South African regime. Again, the regime nationalized the British Petroleum (BP) for supplying oil to South Africa and also for British prevarication on the Rhodesian question. This was at a time, when South Africa blacks needed action and not just the rhetoric to give momentum to the struggle for freedom from the white masters. These were no mean and easy decisions. These were decisions that carried very enormous political implications. These 
decisions were capable of attracting serious political, economic and social reprisals. However, "for the love of our brothers and sisters in South Africa, Nigeria risked all, to help South Africa gain freedom" (Lamido, 15).

Nigeria is also reputed to have provided secret military training at the Kaduna First Mechanized Amy Division and provided other material, financial and diplomatic support to the African National Congress guerrilla forces. In tandem with foregoing, Otubanjo (132) asks: "who can quantify the millions of dollars, that Nigeria spent on the A. N. C. during the struggle to liberate South Africa?"

Furthermore, to help South Africa gain independence, Nigeria led a boycott of the 1978 Games in protest of New Zealand's sporting contacts with Apartheid South Africa, and 32 of 59 nations from Africa, Asia, and the Caribbean joined a Nigeria led boycott of the 1986 Commonwealth Games due to the Thatcher government's attitude towards South African. Nigeria, a member of the Commonwealth mobilized its diplomatic influence and led majority of the Commonwealth countries to boycott these Commonwealth games as a show of solidarity to South Africa and to send a message to the Apartheid supporters in Commonwealth and in the world generally, that Nigeria will fight with all, to ensure the independence of South Africa from the clutches of Apartheid. This by all indications was a herculean task. Nonetheless, it deeply tested Nigeria's claim to leadership in Africa and beyond. What is more, the mobilization was very successful; as the Commonwealth games, that year, was a sorry story. From that moment onwards, the whole world took notice and the struggle for the liberation of South Africa was immediately hyper-accelerated. Nigeria's efforts and a host of other changes in the international system were to work singly and in combination; resulting in South Africa independence in 1994.

The real question begging for an urgent answer is: what actually has Nigeria gained by sticking her neck out in an Africanistvalue- orientated policy in South Africa? South Africans claim that Nigeria did not help South Africa but only the ANC. The foolhardiness in such a position is revealed when one is forced to ask: would South African independence have been possible outside the rugged and dogged nationalism of the ANC? The recent (2015) 
xenophobic attacks against Nigerians and other black Africans in South Africa go to buttress the near uselessness of basing Nigeria's I.R on African values and interests. In fact, it is not erroneous to argue that Nigeria's Africanist assistance to South Africa has turned to haunt Nigeria. Ugwuja, Ibekilo and Ekesiobi contend that "it cannot be denied that South Africa has often leveraged on her position in these alliances (her selective cooperation with emerging economies) to frustrate Nigeria's interests within and outside the African continent" (19).

\section{The Case of Ghana}

Nigeria's bilateral relations with Ghana has revealed some dimensions portraying Nigeria's African values and interests in international relations engagement as antithetical to her core national interests. Although, Nigeria cannot be said to have been a Santa Claus to Ghana, nonetheless Nigeria's financial large - heartedness has in more than one occasion benefited Ghana immensely. Recall that for years, until quite recently Nigeria supplied Ghana with a consequential amount of its energy resources, especially petroleum. Indeed, before 1997, Ghana was known to owe Nigeria tremendously. Some of the debt were written off and out rightly cancelled. But what has Nigeria gained from all these? Nothing significant; except insulting remarks about Nigeria from Ghana, its rulers and masses inclusive; a Ghanaian high - ranking leader was known to have referred to Nigeria as "a lame giant".

Furthermore, the discovery of oil in commercial quantity in Ghana has ossified their disdain for Nigeria. The Ghanaian ministry of trade and commerce has gone to the extent of erecting trade barriers against Nigerian traders doing business in their country and often Nigerian citizens, especially, traders are treated with levity. The effect of these for Nigeria's citizens and international relations is that of country whose citizens are scarcely proud of her achievements. And since external image is undeniably crucial in I.R, Nigeria continues to a project an image of careless and excessive emotional people. This does the country no good in the seeming squalid game of I.R. Therefore, something has to be done about these problems and urgently, too. The next and final section discusses the remedies for these ills in Nigeria's I.R. 


\section{Conclusion and Recommendations}

Nigeria's international relations contrived on the basis of African values and interests were born of historical circumstances and that foreign policy thrust appeared to have served some purpose when it did but does not appear to continue to do so in today's international realities. There is therefore, a pressing need to overhaul and reinvent not only the foreign policy processes of the country but also to dismantle its philosophical foundations.

In line with the above, this study recommends the recreation, elaboration and expansion of the objectives of Nigeria's I.R. As L.A Jinadu has argued, there is no tinge of critical philosophy in Nigeria's foreign policy (17). Secondly, this study canvasses the need for a 'new economic diplomacy' in Nigeria's foreign policy. In this new I.R posture, Nigeria should craft and deploy policies which should aim at making Angola and South Africa pay reciprocate for the numerous assistance rendered to them which has become objects of scorn and derision by these countries. Nigeria, for example can employ aggressive economic diplomacy in its bilateral relations with South Africa; at least partial or full nationalization of their top investments in Nigeria would send the right signals and teach South Africans to treat Nigerians more humanely. The fledging businesses owned by Nigerians and quoted in the South African Stock Market should not foreclose the above objective, the gains of nationalizing the South African owned MTN alone can compensate for whatever retaliatory economic measures that may be put up by South Africa.

Since I.R has an undeniable nexus with domestic affairs, Nigeria should endeavor to forestall the teething signposts of a failing state such as insecurity, ethnicity, religious bigotry, intra and inter regional acrimonies, corruption and moral decadence and lack of sincere leadership.Nigeria's I.R should be made more global; as indeed mutual bilateral relationships should be developed with the emerging nations of Asia and South America. Finally, all appointments to Nigeria foreign missions and employments should be based on purely technical expertise instead of overt political considerations. 


\section{References}

Ade - Ibijola, A. O., "Overview of National Interest, Continuities and Flaws in Nigeria's Foreign Policy",International Journal of Academic Research in Social Science, (3) 1 (January 2013).

Azikiwe, N., Respect for Human Dignity, An Inaugural Address Delivered by His Excellency, Rt. Hon. Dr. NnamdiAzikiwe, on the Occasion of the Country's Independence, Enugu: Government Printers, 1960.

Gambari, A. I, "Nigeria and the United Nations: the Pursuit of National Interest ThroughMultinationalism in a Changing World Order", U. Joy Ogwu (ed), New Horizons for Nigeria on World Affairs, Lagos: N11A, 2005.

Griffiths, M.,Calalhaon, T., andRoach, C.S., International Relations: the Key Concepts, ( $2^{\text {nd }}$ edition) London: Rutledge, 2008.

Igboin, B.O., "Colonialism and African Values", African Journal of History and Culture (3) 1, (July, 2011).

Jinadu, L.A., "The Philosophical Foundations and Fundamental Principles of Nigeria's Foreign Policy" U. Joy Ogwu (ed), New Horizons for Nigeria on World Affairs, Lagos: N11A, 2005.

Joseph Garba, Diplomatic Soldering in the Conduct of Nigerian Foreign Policy, 1975-1979, Ibadan: Spectrum Books Ltd, 1991.

Nawnolue, B.O.G and Iwuoha, V.C., "A Reflection Of Nigeria's Past, 'Africa as The Centerpiece Of Nigeria's Foreign Policy Revisited”, Developing Country's Studies(2) 4, (2012).

Nkrumah, K., Consciencism: Philosphy and Ideology for Decolonization with Particular Reference to the African Revolution, London: Panaf Books Ltd, 1970.

Otubanjo, F., "The Operation and Management of Nigeria's Foreign Policy System: Reflections on the Experience of the First Thirty Years", Gabriel O. Olusanya and R.A. Akindele (eds), The Structure and Processes of Foreign Policy Making and Implementation in Nigeria, 1960-1990, Ibadan: Vantage Publishers, 1990.

Quaison - Sackey, A., Africa Unbound, London: Andre Deutsch Ltd, 1963. 
Saliu, H., “Nigeria's External Image,"Nigerian Journal Of International Affairs, (28), 1 \& 2, 2002.

SuleLamido, "Challenges of Foreign Policy Making and Implementation in Nigeria: An Insider's Perspective", A lecture presented at The Society For International Relations Awareness (SIRA) in collaboration with Fredrick Elbert Stitung (FES)- Nigeria, at Protea Hotel, Asokoro, Abuja,Nigeria, on $31^{\text {st }}$ October, 2012.

Ugwuja, A.A, Ibekilo, C.B., and Ekesiobi, C., "Selective Cooperation in the Global South: Implications for Nigeria's International Economic Relations, 2000 - 2010”, Journal of Research on the Humanities and Social Sciences, (5) 10. (May, 2015).

Ugwune, C.A., “Nigeria's Big Brother Role in Africa's International Relations: Impact On Nigeria National Interest, 1975-2012", A Master's Thesis submitted to the Department of History and International Studies, Nnamdi Azikiwe University, March 2013.

Ukeje, I., Nigeria's Foreign Policy and Great Power Politics, Enugu: Chinedum Publishers Ltd, 1999.

Wendt, A., "Collective Identity Formation and International State", American Political Science Review, (88), 1994. 